УДК 330.341.1

DOI: https://doi.org/10.37320/2415-3583/18.7

Ліпич Л.Г.

доктор економічних наук, професор Луцький національний технічний університет ORCID: https://orcid.org/0000-0002-9059-7271

Хілуха О.А.

кандидат економічних наук, доцент Львівський університет бізнесу та права ORCID: https://orcid.org/0000-0002-1228-7171

Кушнір М.A. кандидат економічних наук, старший викладач Украӥнський католицький університет ORCID: https://orcid.org/0000-0002-4441-4278

\title{
ЛОГІСТИЧНА ПІДТРИМКА ТРАНСФЕРУ ЗНАНЬ ЗІ СФЕРИ НАУКИ ДО СЕКТОРУ МАЛИХ ТА СЕРЕДНІХ ПІДПРИЕМСТВ
}

Основна мета трансферу технологій - це формування економіки знань та ї̈ інтеграція у світове господарство на нових принципах імплементації інновацій. Установлено, щзо розвиток економіки знань вимагає нових підходів до учасників процесів, пов'язаних зі створенням, нагромадженням та розповсюдженням знань. Трансфер знань є мостом між тими, хто їх створює, та тими, хто їх потребує.

Сформовано модель передачі знань зі сфери науки у сферу малого та середнього бізнесу з елементами логістичних потоків. Доведено ефективність використання у відносинах між сферою науки та промисловості стратегії ефективноого обслуговування споживачів. Логістичний та маркетинговий аспекти передачі знань щодо стратегї̈ ефективного обслуговування (ECR) включають такі заходи: постійний наголос на забезпеченні одержувача найкрашим товаром; побудова відносин між сферою науки і промисловістю на моделі win/win; вчасне забезпечення інформацією; знання, передані зі сфери науки у сферу промисловості, використовуються для створення доданої вартості; ефективність системи передачі знань контролюється, аналізується та очінюється обома сторонами, які беруть участь у процесі передачі знань.

Ключові слова: економіка знань, трансфер знань, модель передачі знань, логістична діяльність, стратегії ефективноого обслуговування споживачів - ECR (Efficient Consumer Response), модель win/win.

Постановка проблеми. Питання передачі знань зі сфери науки промисловим реципієнтам знаходиться у центрі інтересів Європейського Союзу у зв'язку 3 переходом до економіки, заснованої на знаннях. В Україні реалізація державної політики щодо трансферу технологій регулюється Законом України «Про державне регулювання діяльності у сфері трансферу технологій» [1].

У більшості регіонів України діяльність, спрямована на зміцнення інновацій та передачу знань та технологій, розпорошена та фрагментарна. Це стосується ресурсів, компетентностей, дослідницької інфраструк- тури та інфраструктури підтримки інновації та трансферу технологій. Що стосується об'єктів, дослідження, то передача знань із сектору науки до промислових підприємств супроводжується численними перешкодами як із боку наукового, так і з боку промислового сектору. Одна з головних проблем щодо комерціалізації знань i технологій пов'язана 3 відсутністю співпраці між ними. Взаємна недовіра між економічними суб' єктами, науковим сектором та державними органами, відсутність традицій та моделей співпраці в українському суспільстві є основними перешкодами для розвитку економіки знань. 
Іншою проблемою $є$ відсутність в Україні добре розроблених механізмів державно-приватного партнерства. Найскладнішим для підприємств $є$ придбання інноваційних компетентностей, тісно пов'язаних зі знаннями, результатом навчання, власним та чужим досвідом, отриманими під час реалізації інноваційних проєктів, адже, створюючи підприємства нового типу (інноваційні підприємства), малий та середній бізнес (МСБ) ставить перед собою завдання, пов'язані з набуттям знань $з$ управління, технологій, техніки.

Аналіз останніх досліджень і публікацій. Науково-практичні аспекти інноваційного розвитку та трансферу технологій досліджено у низці наукових праць вітчизняних та зарубіжних учених: У.Ю. Альварадо [5], М.М. Баб'яка [2], Б. Джонсона [3], Х. Коцаба [5] Б. Лундваля [3], В. Твіса [4] та ін. У дослідженнях науковців висвітлюються загальні економічні проблеми організації та сталого інноваційного розвитку. розглядаються особливості трансферу технологій у ринкову економіку. Основна мета трансферу технологій - це формування економіки знань та їі інтеграція у світове господарство на нових принципах імплементації інновацій. Зазначимо, що визначення напрямів активізації трансферу інноваційних технологій у МСБ України пов'язане $з$ дослідженням особливостей розвитку заходів його логістичної підтримки як інструменту активізації, комерціалізації та соціалізації трансферу технологій та сталого розвитку вітчизняного ринку інновацій. На жаль, аналіз питань визначення взаємозв'язку результативності трансферу технологій від ефективності реалізації логістичної підтримки вивчено у науковій літературі недостатньо.

Мета статті полягає у характеристиці засобів логістичної підтримки процесу трансферу знань зі сфери науки у сферу промисловості, зокрема сектору МСБ.

Виклад основного матеріалу. Підприємства сектору МСБ становлять більшість підприємств, що працюють в українській економічній реальності. Зміни, що полягають у коригуванні діяльності підприємства до очікувань зовнішнього середовища, особливо тих, що передбачають упровадження інновацій у вигляді нових технічних, технологічних та організаційних рішень, впливають на розвиток та конкурентоспроможність цих підприємств. Малий та середній бізнес в економіці держави виконує низку специфічних соціально-економічних функцій:

1.Сприяє процесам демонополізації, приватизації та роздержавлення економіки, стимулюванню розвитку економічної конкуренції, формуванню численних суб'єктів ринкового господарства, орієнтованих на попит, конкуренцію тощо.

2.Залучає до економічного обороту матеріальні, природні, фінансові, людські та інформаційні ресурси, які «випадають» із поля зору великих компаній.

3.Поліпшує становище на ринках шляхом забезпечення еластичності їхньої структури, врегулювання попиту, пропозиції і цін, принаймні часткової компенсації втрат пропозиції на період реструктуризації великих компаній, індивідуалізації пропозиції та диференціації попиту, насичення ринків, задоволення специфічних місцевих потреб.

4.Вивільняє великі підприємства від виробництва нерентабельної для них дрібносерійної та штучної продукції, яка задовольняє індивідуальний попит і підвищує тим самим ефективність їхньої діяльності. Великим компаніям укладення коопераційних угод 3 малими підприємствами дає змогу підвищити гнучкість виробництва, зменшити комерційний ризик.

5.Забезпечує додаткові робочі місця та місця працівникам, вивільненим у процесі реструктуризації великих підприємств.

6. Стимулює підвищення ділової активності населення та розвитку середнього класу, який становить соціальну базу економічних реформ і забезпечує стабільність суспільства.

7.Пом'якшує соціальну напругу завдяки ослабленню майнової диференціації та підвищенню рівня доходів населення.

8.Збільшує гнучкість національної економіки та ринкової пропозиції відповідно до сучасних умов відкритої економіки.

9. Сприяє процесу демократизації суспільства, раціоналізації системи економічної організації та управління [2, с. 77].

Аналіз діяльності підприємств МСБ, показав, що вони не $\epsilon$ активними у всіх сферах управління, і переважна більшість опитаних не має і не формує ринкові стратегії. Виникає питання, як і чи це впливає на ефективність сектору, його частку в економіці та на його розвиток в довгостроковій перспективі. Українські підприємства МСБ не зацікавлені у співпраці зі світом науки, і лише $8 \%$ iз них уважають дослідження та розробки способом отримання конкурентних переваг.

Малі та середні підприємства орієнтуються на короткострокове планування - максимальне використання ресурсів та інвестування у збільшення виробничих потужностей. 3 іншого боку, авторські дослідження показують, що МСБ, особливо мікропідприємства, не зацікавлені в упровадженні суттєво нової, інноваційної продукції, а лише вдосконалюють існуючу. Менше 1\% підприємств цікавилися інноваціями як інструментом формування конкурентних позицій. Єдиною конкурентною стратегією була цінова, і підприємства, у тому числі малі та середні, порівнюючи себе з конкурентами в країнах $\mathrm{CC}$, чітко вказали свої цінові переваги.

Серед чинників, що стимулюють діяльність підприємств МСБ, найважливішими напрямами є організування та управління, сфера інновацій та задоволення вимог клієнта. Чинники, що стимулюють розвиток підприємств МСБ, представлено на рис. 1.

Дослідження авторів, проведене на підприємствах малого та середнього бізнесу в IT-секторі та на транспортних підприємствах, засвідчили, що небагато 3 них сформулювали ринкову стратегію розвитку, використовуючи знання в галузі маркетингу та управління логістикою, спираючись на моделі, представлені в літературі із цього питання. Особливо великі диспропорції мали місце між мікро- та середніми підприємствами, які намагалися побудувати системи управління, засновані на системах, що використовуються у великих підприємствах, із надрегіональним та глобальним охопленням.

Ті підприємства, що формували стратегії розвитку, включаючи інноваційну стратегію, особливо стосовно маркетингової та логістичної діяльності, стикалися 3 труднощами вже на етапі формування стратегічних 


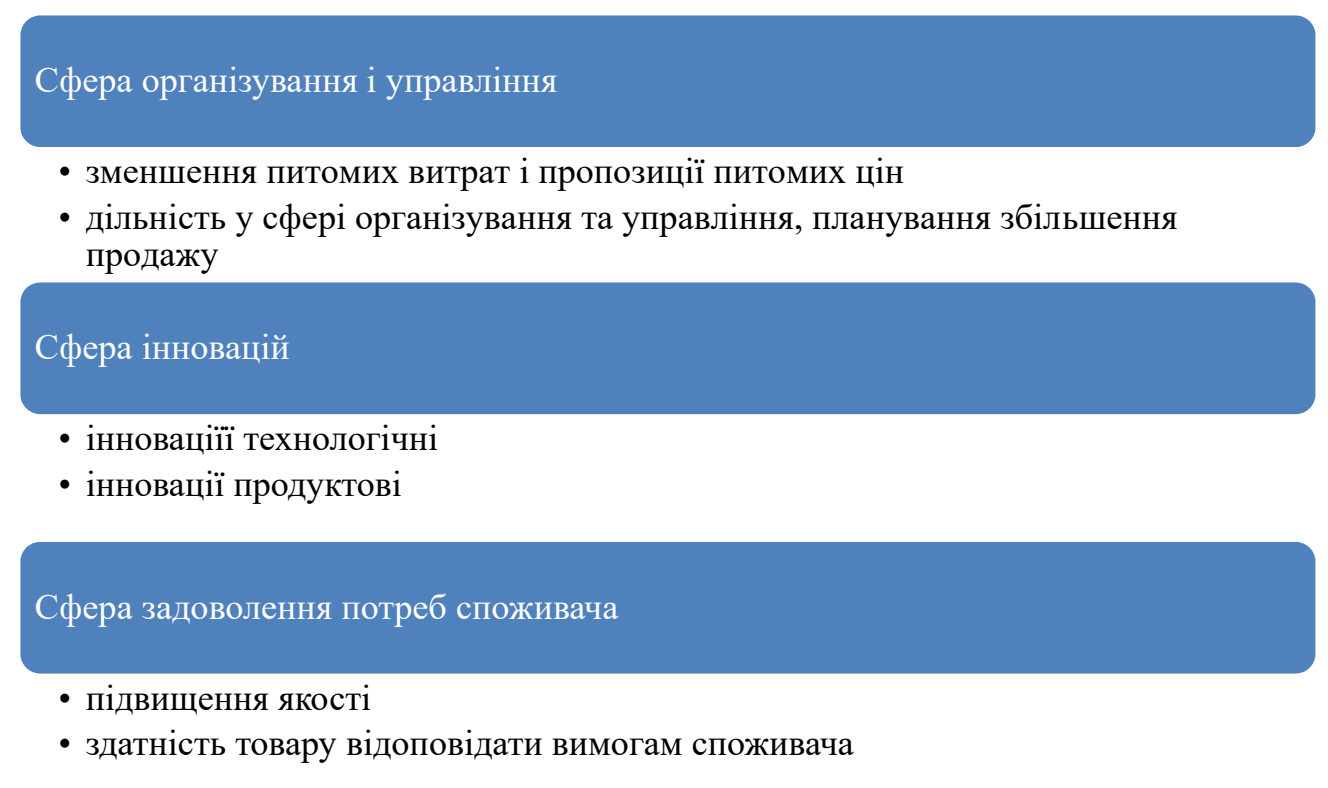

Рисунок 1 - Чинники, що стимулюють розвиток підприємств МСБ

Джерело: авторська розробка

цілей через високий рівень ризику ведення бізнесу, нерозуміння конкурентного середовища та страх невдач.

Розвиток економіки, заснованої на знаннях, вимагає нових підходів до знань як до ресурсу і до учасників усіх процесів, пов'язаних зі створенням, нагромадженням та розповсюдженням знань. Учасники процесу знань це науково-дослідні організації, що є креаторами знань, та споживачі знань, якими можуть бути інші наукові організації, виробничі та сервісні підприємства. Дослідження трансферу технологій закладами вищої освіти Міністерства освіти і науки України (далі - ЗВО) здійснено на основі щорічного моніторингу реалізації пріоритетних напрямів інноваційної діяльності [1]. Технології передано на внутрішньому (974 технології, або 94,8\%) та зовнішньому (53 технології, або 5,2\%) ринках. Від передання технологій на внутрішньому ринку надійшло 91,9\% загального обсягу, на зовнішньому $8,1 \%$. Переважну більшість технологій $(918$, або 89,4\%) передано промисловим підприємствам. Серед усіх ЗВО найбільш активно здійснювали діяльність із трансферу технологій шість закладів, якими передано 89,2\% технологій. Першу позицію займає Сумський державний університет із 788 переданими технологіями, другу позицію - Національний університет харчових технологій із 53 технологіями.

Учасники процесу знань, взаємодіючи між собою, створюють сферу, яку можна назвати ринком продуктів знань. Знання стають «продуктом», який може мати форму прихованих (неявних) або явних, актуальних знань. Б. Лундваль та Б. Джонсон (B. Lundval i B. Johnson) [3] виокремлють два види знань: know what oraz know how (знати що, знати як). Залежно від виду знань можна говорити про різні шляхи їх трансферу та передачі. Спосіб, яким знання, що виникають у науковій сфері, будуть передані в сферу промисловості, зокрема на підприємства МСБ, повинен відповідати попиту на знання у цьому секторі. Тобто слід говорити про двосторонні відносини учасників процесу передачі знань, від яких залежить їх вид та обсяг. Економіка знаннь зорієнтована на передачу ідей, результатів досліджень та навичок наукових структур групам користувачів, тому трансфер знань $є$ мостом між тими, хто їх створює та тими, хто їх потребує. Трансфер знань залежить від:

- виду знань, що передаються;

- типу завдань, для виконання яких ці знання потрібні;

- обставин, за яких слід використовувати ці знання;

- учасників процесу передачі знань.

Таким чином, нові знання, новий досвід та навички, створені в процесі реалізації інноваційного процесу, створюють нові цінності та впливають на формування суспільства, заснованого на знаннях. Згідно 3 дослідженнями В. Твіс (Twiss B.), для того щоб формувати попит на знання, розвиток підприємства вимагає здатності визначати інноваційний розрив (технологічний розрив) $[4$, с. 56]. Наступні фази інноваційного процесу назвемо ланцюгом створення інноваційної вартості. Таким чином, під ланцюжком створення інноваційної вартості слід розуміти послідовність фаз (етапів) - від інноваційної ідеї до дослідницької програми через фундаментальні та прикладні дослідження, розробки, впровадження до практичних застосувань, тобто її реалізації. Результатом процесу впровадження є інновації.

Трансфер знань стає платформою для впровадження змін шляхом генерування інновацій на підприємстві; таким чином, передача знань веде до розвитку організації. Інновації вносять зміни в економічні та соціальні системи, наслідком яких є:

- підвищення комфортності використання продуктів (послуг) процесів та систем управління;

- підвищення ефективності управління;

- захист природного середовища;

- краща міжособистісна комунікація;

- поліпшення якості життя в суспільстві. 
Логістична діяльність включає матеріальні потоки, що супроводжують передачу знань, такі як передача документації, патентів, реалізація пілотних проєктів, створення прототипів, презентація методів і технологій тощо.

Пошук чинників логістичної підтримки в процесі передачі знань зі сфери науки до сектору МСП пов'язаний із моделлю створення ланцюжка доданої вартості. Модель передачі знань із сфери науки у сферу промисловості (МСП) разом з елементами логістичних потоків показано на рис. 2.

Передача знань із сфери науки до сектору МСБ, що підтримується логістичною діяльністю, може призвести до запуску інноваційного процесу. Однією зі стратегій, яка може бути використана у відносинах між сферою науки та промисловості, включаючи сектор малого та середнього бізнесу, є стратегія ефективної обслуговування споживачів - ECR (Efficient Consumer Response) [5]; інформаційні потоки: тренінги, презентації, лекції, консультації, практичні заняття та відпрацювання навичок та прийомів.

Ця стратегія спрямована на досягнення максимально високого рівня обслуговування споживачів: у разі передачі знань замовником $є$ підприємство із сектору МСБ. Стратегія ECR може стати важливим інструментом підтримки передачі знань зі сфери науки до галузі через необхідність тісної співпраці між партнерами. Логістичний та маркетинговий аспекти передачі знань щодо стратегії ефективного обслуговування (ECR) включають такі заходи:

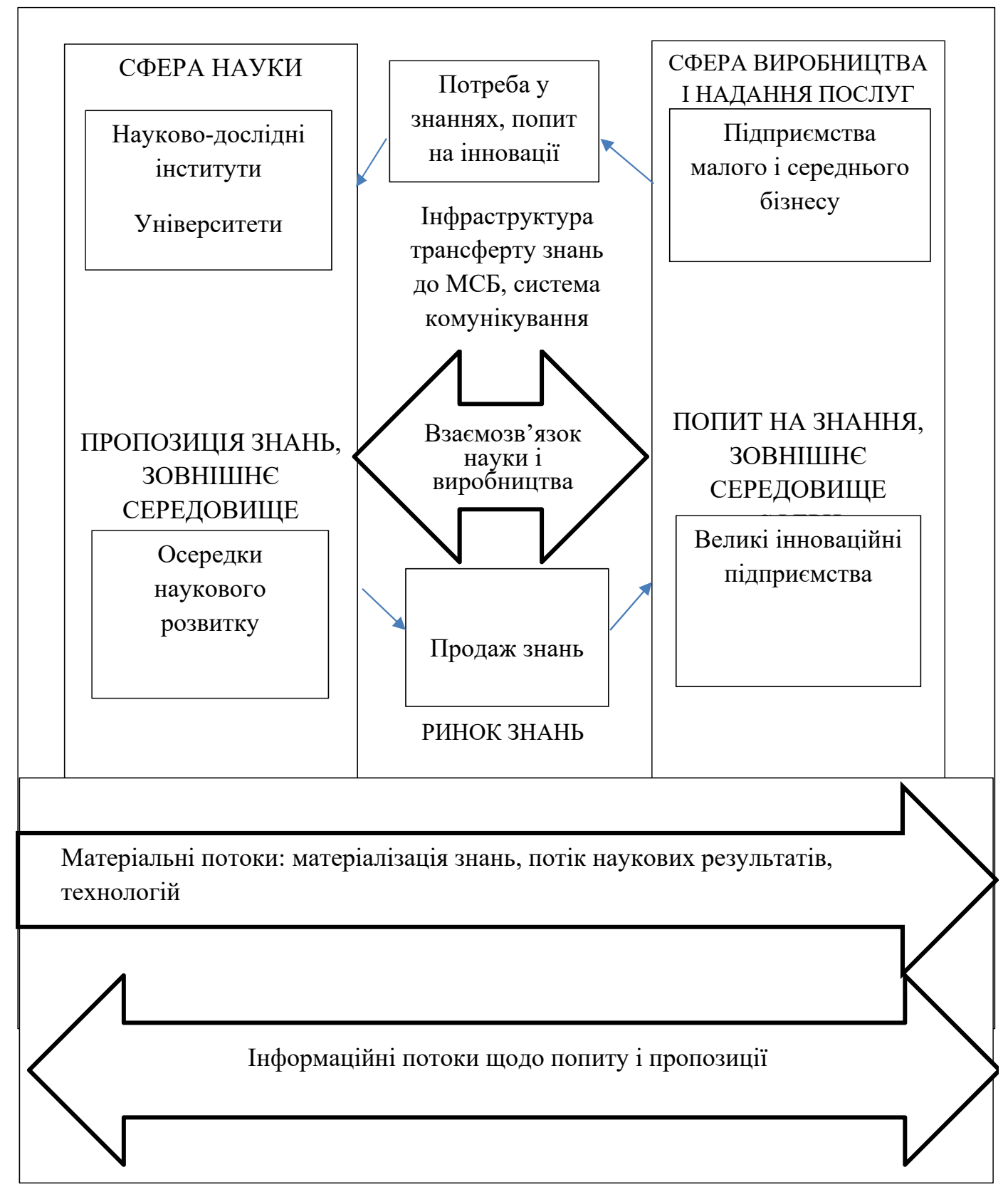

Рисунок 2 - Модель транферу знань зі сфери науки до МСБ 
1) постійний наголос на забезпеченні одержувача найкращим товаром (в даному разі товар - це знання);

2) відносини між сферою науки і промисловістю базуються на моделі win/win у зв'язку 3 реалізацією спільної мети;

3) інформація доводиться вчасно, для цього використовуються сучасні засоби передачі інформації;

4) знання, передані зі сфери науки у сферу промисловості, використовуються для створення доданої вартості, а кінцевий результат створюється в потрібному місці та в зазначений час;

5) ефективність системи передачі знань контролюється, аналізується та оцінюється обома сторонами, які беруть участь у процесі передачі знань.

Ефекти від проникнення знань у сектор МСБ проявляються у створенні, впровадженні та розповсюдженні інновацій. Залежно від стандарту логістичної підтримки трансферу знань їхні результати проявляються у секторі МСБ через:

- збільшення участі МСП у секторах створення інноваційної продукції (послуг);

- зміну питомої ваги МСП у традиційних та нових продуктах (high-tech, super high-tech, easy-tech);

- появу нових факторів виробництва у різних галузях виробництва та надання послуг;

- зацікавленість МСБ у зміні пропорції між традиційними та сучасними технологіями (екологічними, безвідходними);

- збільшення частки інноваційної продукції на існуючих ринках МСБ та сегментах споживачів;

- появу нових сегментів споживачів - покупців товарів та послуг МСБ.

У макроекономічному масштабі в довгостроковій перспективі ефект накопичення знань у секторі МСБ може бути позначений змінами у структурі споживання, зменшенням екологічно деградованих зон та розвитком нових та різних форм освіти та навчання. Особливу увагу слід приділити тим підприємствам, які мають конкретні очікування щодо сфери науки та шукають можливість співпраці та консультування. Досягнення позиції на світовому ринку шляхом упровадження стандартів, що вимагаються, наприклад,
$€ C, \epsilon$ відносно простим для великих підприємств із власними підрозділами, що займаються пошуком інформації, навчанням, упровадженням проєктів та інновацій. Ця група компаній має найбільші шанси вийти на ринок ЄС та зміцнити там свої позиції. Для підприємств сектору МСБ певною можливістю збільшити ринкові можливості може бути передача знань із використанням підтримки через логістичну діяльність. Упровадження системи управління логістикою на основі інтелектуального капіталу може бути важливим чинником підвищення конкурентоспроможності підприємства МСБ. 3 їхнього погляду впровадження нових знань повинно стати основою для формулювання розвитку стратегії цих організацій, включаючи:

1. Упровадження нових продуктів, процесів та організаційних систем.

2. Підвищення раціональності управління, що виражається у підвищенні ефективності, зменшенні обсягу факторів виробництва та зростанні їх продуктивності.

3. Підвищення іміджу та репутації організації.

4.Поліпшення інноваційного клімату, а також пошук джерел підвищення інтелектуального потенціалу - його розвиток та вдосконалення.

5.Утримання підприємства на існуючих ринках та розширення ринків збуту.

6.Залучення додаткових коштів для фінансування інноваційних програм.

Висновки. Нині трансфер нових знань із галузі науки до сектору МСБ відбувається занадто повільно і не відповідає очікуванням останніх. Тому в інституціях науки великого інтересу до сектору МСБ як отримувача знань поки що не спостерігається, а отже, трансфер знань обмежений. 3 іншого боку, здатність продукування сектору МСБ та поглинання знань на разі $\epsilon$ відносно низькою, що спонукає до пошуку інструментів, які суттєво змінюють рівень знань у цьому секторі. Логістичне забезпечення процесу трансферу знань із наукового сектору до промислового, особливо до сектору МСБ, є важливим елементом, що підтримує як матеріальний потік, так і потік інформації в галузі передачі знань.

\section{Список використаних джерел:}

1. Про державне регулювання діяльності у сфері трансферу технологій : Закон України від 14.09.2006 № 143-V / Верховна Рада України. URL: https://zakon.rada.gov.ua/laws/show/143-16\#Text.

2. Баб’як М.М. Розвиток малого і середнього підприємництва у регіоні. Актуальні проблеми економіки. 2004. № 12. C. $77-83$.

3.Lundvall B.-A., Johnson,B. The learning economy. Journal of Industry Studies. 1994. Vol. 1. № 2. P. $23-42$.

4.Twiss B.C. Managing Technological Innovation, Pitman Publishing. London, 1994.

5. Alvarado U.Y., Kotzab H. Supply Chain Management: The Integration of Logistics in Marketing. Industrial Marketing Management. 2001. № 30. P. 183-198.

\section{References:}

1. On state regulation of activities in the field of technology transfer: Law of Ukraine of 14.09.2006 No 143-V.Verkhovna Rada of Ukraine. Available at: https://zakon.rada.gov.ua/laws/show/143-16\#Text.

2. Babiak M.M. (2004) Rozvytok maloho i serednoho pidpryiemnytstva u rehioni [Development of small and medium business in the region]. Aktualni problemy ekonomiky, no. 12, pp. 77-83.

3. Lundvall B.-A., Johnson B. (1994) The learning economy. Journal of Industry Studies, vol. 1, no. 2. pp. $23-42$.

4. Twiss B.C. (1994) Managing Technological Innovation, Pitman Publishing. London.

5. Alvarado U.Y., Kotzab H. (2001) Supply Chain Management: The Integration of Logistics in Marketing. Industrial Marketing Management, no. 30, pp. 183-198. Elsevier Science Inc. 
Lipych Lubov

Lutsk National Technical University

Khilukha Oksana

Lviv University of Business and Law

Kushnir Myroslava

Ukrainian Catholic University

\section{LOGISTIC SUPPORT FOR THE KNOWLEDGE TRANSFER FROM THE FIELD OF SCIENCE TO THE SECTOR OF SMALL AND MEDIUM BUSINESS}

The main purpose of technology transfer is the formation of the knowledge economy and its integration into the world economy on the new principles of innovation implementation. The purpose of the article is to characterize the means of logistical support of the process of knowledge transfer from science to industry, the SME sector.

Analysis of the activities of SMEs showed that they are not active in all areas of management, and the vast majority of respondents do not have and do not form a market strategy. Small and medium-sized enterprises focus on shortterm planning - maximizing the use of resources and investing in increasing production capacity. On the other hand, SMEs are not interested in introducing significantly new, innovative products, but only improve existing ones. Among the factors that stimulate the activities of SMEs, the most important are: organization and management, innovation and customer satisfaction. It has been established that the development of a knowledge-based economy requires new approaches to knowledge and to participants in all processes related to the creation, accumulation and dissemination of knowledge. Knowledge transfer is a bridge between those who create it and those who need it.

The model of knowledge transfer from the sphere of science to the sphere of small and medium business with elements of logistic flows is formed. It is substantiated that the transfer of knowledge from the field of science to the SME sector, which is supported by logistics activities, leads to the launch of the innovation process. The efficiency of use in the relationship between science and industry, including the small and medium business sector, the strategy of Efficient Consumer Response. The logistical and marketing aspects of the transfer of knowledge on the strategy of Efficient Consumer Response (ECR) include the following activities: constant emphasis on providing the recipient with the best product; building relations between science and industry on a win / win model; timely provision of information; knowledge transferred from the field of science to the field of industry is used to create added value; the effectiveness of the knowledge transfer system is monitored, analyzed and evaluated by both parties involved in the knowledge transfer process.

Key words: knowledge economies, knowledge transfer, knowledge transfer model, logistics activity, strategies of Efficient Consumer Response (ECR), win / win model.

JEL classification: I20, I25 